\title{
Spatio-Temporal Variations of Rainfall and SST Anomaly over Indonesia during ENSO Modoki Event in 2010
}

\author{
Abd. Rahman As-syakur ${ }^{a *}$ \\ ${ }^{a}$ Faculty of Marine Science and Fisheries, Udayana University, Bukit Jimbaran, Bali 80361, Indonesia \\ ${ }^{*}$ Corresponding author. Tel.: +62-361-702-802 \\ E-mail: assyakur@unud.ac.id
}

\begin{abstract}
Remote sensing application is one of the best data to observing spatial and temporal situation on earth surface. Application of Tropical Rainfall Measuring Mission (TRMM) and MODIS (Moderate Resolution Imaging Spectro-radiometer) are use for spatial and temporal analysis of rainfall and sea surface temperature (SST) anomaly over Indonesia in 2010. Spatial and temporal rainfall and SST anomaly data is important, especially during El Niño-Southern Oscillation (ENSO) Modoki events, because has wide effect of social and economy in Indonesia. Monthly rainfall data measured by the TRMM 3B43 over the course of 13 years and Monthly SST collected by the MODIS was employed to analyze anomaly of rainfall and SST over Indonesia during ENSO Modoki Event in 2010. In spatiotemporal seen confirmed during ENSO Modoki in 2010 indicate an anomaly has occurred on rainfall and SST over Indonesia. The result shows that increasing of rainfall anomaly begin from April in Nusa Tenggara archipelago and eastern of Java and finish in November in those region. Meanwhile, analysis result of MODIS satellite data for SST anomaly is shown at the beginning of 2010, SST anomaly begin occurred in western of Indonesia and the biggest was happen in southern of Indonesia at August to September and finish at November. Spatio-temporal analysis TRMM dan MODIS data shows that increasing of SST anomaly could affect increasing of rainfall anomaly in those same regions excepted in January to March.
\end{abstract}

Keywords: TRMM; MODIS; rainfall anomaly; SST anomaly

\section{Introduction}

The world ocean plays an important role in the earth climate. It is not only absorbs heat from the sun, but plays a major role in rainfall variability in Indonesia. For long term climate forecasts, knowledge of the heat, momentum, and substance exchange between the atmosphere and the ocean is essential because the time constants and capacities of the ocean are much larger than those of the atmosphere (Baliño et al. 2001). Indonesia, along with equatorial Africa and South America, is recognized as a primary energy source for the entire global circulation system. The main supply of energy is latent heating, released from the condensation of water vapor when clouds and precipitation form due to cumulus convection (Qu et al., 2005)

Indonesia is located in equator between two continents and two oceans. This location could affect Indonesia by two circulations, Hadley and Walker, which affect the rainfall in Indonesia (Aldrian et al., 2007). Monsoonal activity and regional topography also play an important role in macro and micro scale of rainfall variability (Aldrian and Djamil, 2008; As-syakur et al., 2013). ElNino Southern Ocilation (ENSO) which consist El-Nino and La Nina event, for example, is an anomally that effect rainfall variability in global and regional scale (Lou et al., 2010). ENSO is a coupled ocean-atmosphere phenomenon of the tropical Pacific. La Nina caused dry season become wet than normal condition, rainy season become earlier, and higher sea surface temperature (SST) in Indonesia (Philander, 1990; Bell et al., 1999; Bell et al., 2000; Hamada et al., 2002; Hendon, 2003a; As-syakur, 2010;
As-syakur and Prasetia, 2010; Tjasyono et al., 2008). On the other hand, La Niña causing sea-surface temperatures below to average in the center of Pacific Ocean commonly occur following an El Niño and appear to be associated with weather events opposite that of El Niño (As-syakur et al., 2014). Monsoons in the Indian Ocean are wetter than normal while summers in North America are hot and dry. However, winters in northern North America have set records for cold temperatures and snowfall, with an increase in devastating tornadoes in the south during $\mathrm{La}$ Niña events (Water Encyclopedia, 2011). The year of 2009/10 and 2010/11 have the strongest El Nino and La Nina event which affected rainfall and SST in Indonesia (NOAA, 2010). Takahashi et al. (2013) have classified 2009/10 as El Niño Modoki and Platonov et al. (2012) has classified 2010/11 as La Niña Modoki. ENSO Modoki is identified as a type of pseudo-Niño in the tropical Pacific, which is different in obvious ways from the conventional El Niño, particularly in terms of spatial and temporal characteristics, as well as teleconnection patterns (Ashok et al., 2007; Li et al., 2010). El Niño (La Niña) Modoki is characterized by warm (cool) waters in the central Pacific and cool (warm) waters in the eastern and western parts of the basin (Feng and Li, 2011; Xie et al., 2014).

Meanwhile, local air-sea interactions in Indonesian sea also contribute to the Indonesian rainfall variability (Hendon, 2003a; 2003b). The SSTs across the Indonesian region are of paramount importance to convection and, hence, precipitation distribution. Convective activity, which dominates weather in the tropics, is variable on a range of spatial and temporal scales, making the climate of the Indonesian and its relationship to SST fascinating to 
study (Qu et al., 2005). Observational evidence indicates that the SST in this region has notable subseasonal fluctuations (Wu et al., 2008).

Rainfall conditions need a long term observation and a good rainfall data because in Indonesia has a high variability of rainfall. Rain gauge available an accurate and effective data in each location. Meanwhile, the spread of rain gauge can not reach in difficult topography and also in ocean; this could affect lower precise data especially in spatial and temporal rainfall data. These situations effect the rainfall prediction with any climate modelling research (Feidas, 2010). Nowadays, rainfall available data that will use in scientist application could get by satellite of meteorology or remote sensing data application. Satellite remote sensing prepares rainfall data in better distribution of rainfall measurement. Furthermore with composite of any satellite data with rain gauge data will increase the accurate of rainfall data (Petty, 1995; Xie et al., 2007). The completely of rainfall spatial data distribution will be complete the rainfall information.

Tropical Rainfall Measuring Mission (TRMM) Multisatellite Precipitation Analysis (TMPA) is composite product between TRMM Precipitation Radar (PR), TRMM Microwave Imager (TMI), Microwave meteorology image, Infrared, and observation data (Huffman et al., 2007). Previous research shown that TMPA with BMKG result approach similar pattern of rainfall especially in monthly rainfall data (As-syakur et al., 2010; Suryantoro et al., 2008) altough the TMPA value is under estimation of BMKG rainfall data (Assyakur et al., 2010). TMPA, especially type $3 B 43$ is available data for monthly rainfall data. Furthermore, The Moderate Resolution Imaging Spectroradiometer (MODIS) instrument has been designed to provide improved monitoring for land, ocean, and atmosphere research. MODIS is a sensor that could found in Terra (begun orbit at December 1999) and Aqua satellite (begun orbit at May 2002). In this case MODIS is available data for Sea surface temperature (SST) data.

The aims of this research are to know spatial pattern of rainfall and SST anomaly during ENSO Modoki Event in 2010 using remote sensing application (TRMM and MODIS) and to describe the spatial-temporally pattern of the linked between SST and rainfall anomaly in Indonesia sea in 2010.

\section{Research Method}

\subsection{Data}

Monthly Rainfall data periods from January 1998 to December 2010 and SST data periods from March 2000 to February 2011 measured and collected by TMPA for rainfall and MODIS for SST were used to analyze the spatial patterns of rainfall and SST. Cover spatial data used in this research are $20^{\circ} \mathrm{N}$ to $20^{\circ} \mathrm{S}$ and $80^{\circ} \mathrm{E}$ to $160^{\circ}$ E (Figure 1).

The TRMM is cosponsored by the National Aeronautics and Space Administration (NASA) of the USA and the Japan Aerospace Exploration Agency (JAXA, previously known as the National Space Development Agency, or NASDA) and has collected data since November 1997 (Kummerow et al. 2000). TRMM is a long-term research program designed to study the Earth's lands, oceans, air, ice, and life as a total system (Islam and Uyeda 2007). TMPA is a calibration-based sequential scheme for combining precipitation estimates from multiple satellites, gauge analyses where feasible, as well as provides a global coverage of precipitation over $50^{\circ} \mathrm{S}-50^{\circ} \mathrm{N}$ latitude belt at $0.25^{\circ} \times 0.25^{\circ}$ spatial and $3-$ hourly temporal resolutions for $3 \mathrm{~B} 42$ and monthly temporal resolution for 3B43 (Huffman et al., 2007). The TMPA estimates are produced in four stages: (1) the microwave estimates of precipitation are calibrated and combined, (2) infrared precipitation estimates are created using the calibrated microwave precipitation, (3) the microwave and infrared estimates are combined, and (4) rescaling to monthly data is applied (Huffman et al., 2007, 2010). The TMPA retrieval algorithm which used for this product is based on the technique by Huffman et al. (1995, 1997) and Huffman (1997). In this paper, TMPA data types used are 3B43.

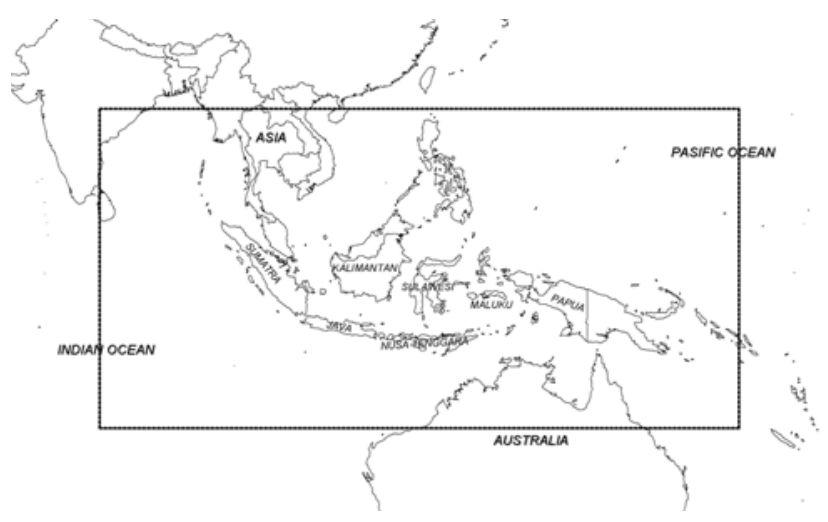

Gambar 1. Spatial cover of research

The SST data is obtained from MODIS sensors. In Terra and Aqua satellite included MODIS sensor ans has a 36 Band Spectral (620-965 nm, 3660-14385) with 3 spectral resolutions $(250 \mathrm{~m}, 500 \mathrm{~m}$, and $1 \mathrm{~km})$. The MODIS spectral band for 8-16 is especially to observe the ocean color. The products are spread of chlorophyll concentration, sea surface temperature, turbidities, and brightness.

MODIS passes south to north over the equator in the afternoon. It's viewing the entire Earth's surface every 1 (one) to 2 (two) days, acquiring data in 36 spectral bands, or groups of wavelengths.. The TMPA 3B43 is citied from the website ftp://disc2.nascom.nasa.gov/data/s4pa/ TRMM_L3/. Meanwhile, the MODIS SST data is citied from the website http://oceancolor.gsfc.nasa.gov/cgi/l3.

\subsection{Methods}

Monthly analysis will be carried out by averaging the monthly data on the same month during year observation. Analysis conducted in each pixel with the coordinates as identity. Data extracted from the TRMM 3B43 and MODIS in each pixel to generate point-by-point data. The 
point has the information about coordina-te, month, year, and rainfall or SST values. Then the data are sorted in accordance with the purposes of analysis. To determine the rainfall and SST percentage fluctuations during 2010, the monthly rainfall data and MODIS SST data is divided by the 13 years average of rainfall and 10 years average of MODIS SST for the same month. The equation to determine the percentage of rainfall and SST anomalies is (As-syakur and Prasetia, 2010):

$$
\text { Anomaly }=\left(\left(\frac{P}{P} \times 100\right)-100\right)
$$

Where $P$ are rainfall/SST at month $m$, while $\bar{P}$ is rainfall or SST average at month $m$ during year observation.

\section{Results and Discussion}

\subsection{Spatial Pattern Rainfall Anomaly}

Figure 2 shown percentage of increasing and decreasing rainfall spatial pattern distri-bution in Indonesia 2010. According to Figure 2, shown that spatial pattern anomaly of increasing rain-fall during March is still low and could be found in small part of Sumatera, Java, west-ern part of Kalimantan, and center part of Sulawesi. Dec-reasing of rainfall anomaly occur in Nusa Tenggara Islands and southerneast part of Sulawesi. Meanwhile, rainfall is normal condition in another part of Indonesia. During April, increasing of rainfall anomaly is beginning to living Sumatera. In Kalimantan the rainfall posi-tion is moving to the center of this island. Meanwhile, in Nusa Tenggara, eastern part of Java Island and northern part of Sulawesi is

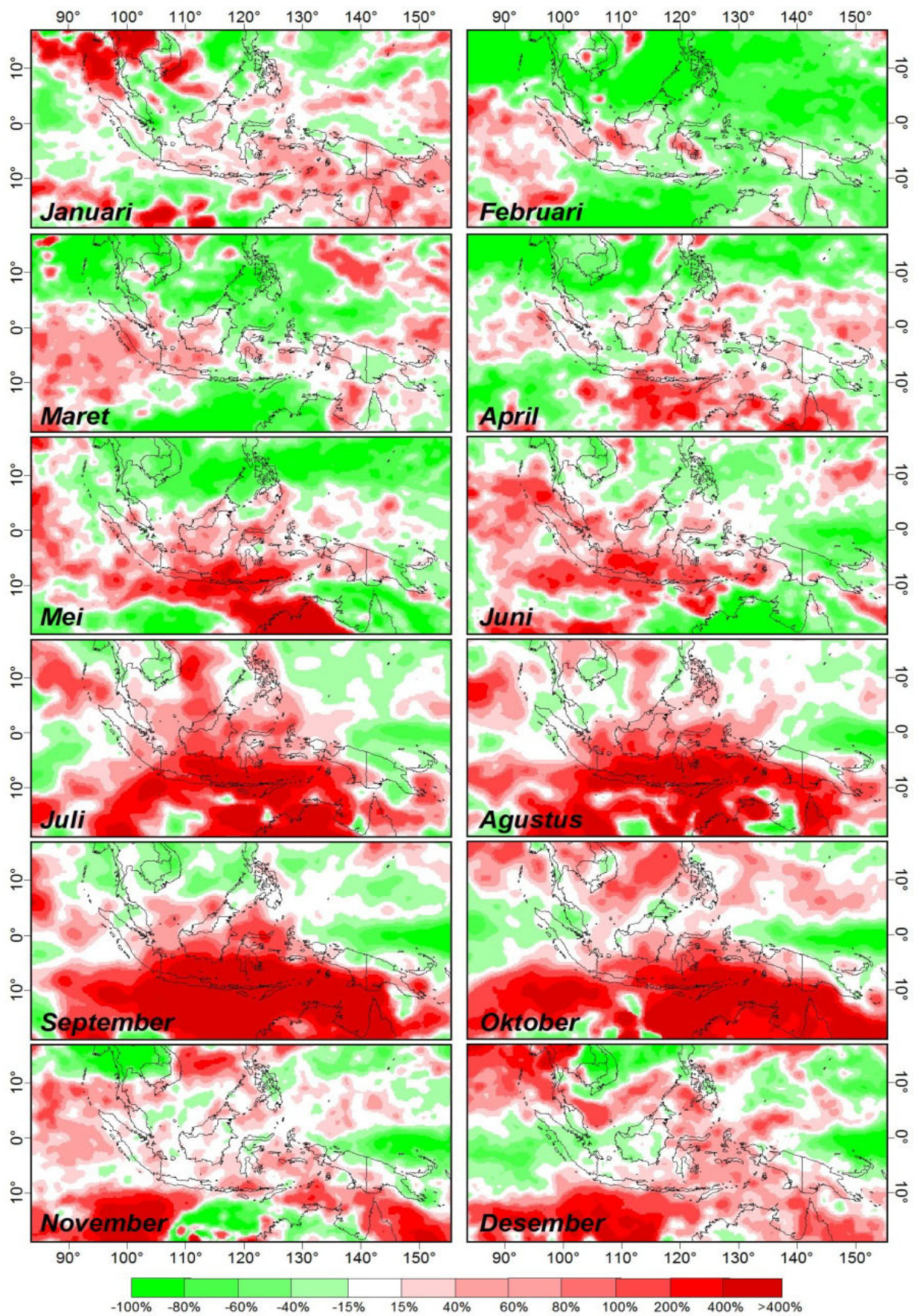
beginning in increasing of extreme rainfall. On May, increasing of rainfall occur in all part of Indonesia from $20 \%$ to $200 \%$. The same condition occurs in northern of Sula-wesi and center of Kaliman-tan, although in lower value than in southern of Indone-sia. Normal rainfall on May is only could be found in Maluku and northern part of Sumatera. During June, the anomaly of rainfall has shown a close figure with rainfall condition on May, although the value is lower and only could be found in Sumatera. The highest rain-fall anomaly (> 400\%) occurs during August to October along and offshore southern part and the center part of Indonesia. During November the rainfall ano-maly began to weaken and continue to occur until De-cember. The rainfall anomaly during November and De-cember occurs more in the eastern part of Indonesia.

Seasonally, rainfall anomaly in Indonesia region occurs during southeast monsoon. Although not happening over Indonesia and only in the southern part of Indonesia. While during the northwest monsoon occurs outside of Indonesian region, especially in southwest and northwest part.

Figure 2. Spatial patterns of rainfall anomaly in 2010 


\subsection{Spatial Pattern SST Anomaly}

Figure 3 shown percentage of increasing and decreasing SST spatial pattern distribution in Indonesia Sea 2010. Anomaly of increasing SST on January begins from western part of Indonesia especially in northernwest part in Natuna Sea. Meanwhile on February until March anomaly of increasing SST moving to southern part of Indonesia. On April, anomalies of SST in western part become lower but begin higher in southern part of Indonesia Sea. Furthermore, on May anomaly of increasing SST is spread evenly in all Indonesia Sea until October. On August and September the highest peak anomaly of increasing SST $(>8 \%)$ is found in southern part of Indonesia especially in Java and Sumatera. On November, this anomaly begin decreasing which marked by normal SST in all part of Indonesia Sea, but in other case that SST anomaly moving to western part of Australian Sea. However, on December anomaly of increasing SST is still in northern west and also in northern east of Indonesia.

\subsection{Spatial relationship} between rainfall and SST Anomaly

Rainfall and SST anomally has similar location in spatial pattern as shown in Figure 2 and 3. The similar patterns locations extremely shown begin in April to October. On April, high anomaly of SST has been shown in southern part of Java Island which is in the same location with high anomaly of rainfall. On May to August, SST anomally is distributed in all part of Indonesia and also the same with rainfall anomally. On September and October, where the high anomally of SST is occurr in southern part of Java also follow with high level nomally of rainfall. This condition has shown that strong relationship between rainfall and SST anomally in Indonesia.

\subsection{Discussion}

The spatial patterns of rainfall and SST anomaly over Indonesia, observed by TRMM 3B43 and MODIS data was explored for the period 1998-2010. Monthly spatial analysis on rainfall and SST anomaly in Indonesia has been done. This study proves that the use of remote sensing data can be used to find the spatial patterns of rainfall and SST anomaly over Indonesia, where the distribution of data was quite capable of providing different information about rainfall anomaly on mainland and sea and spatial relationship between SST anomaly and rainfall anomaly.

Using the remote sensing data to know the spatial pattern of rainfall and SST anomaly is given an interesting spatial pattern. The rainfall anomaly is not only describing in land condition but also has shown the spatial pattern interaction between land and sea (Figure 2 and 3). Furthermore, in spatial condition shown that any similar of and strong relationship between rainfall and SST anomaly in Indonesia. 
Rainfall and SST in the Indonesian regions is strongly affected by the Asia-Australia (AA) monsoon system: the southeast and northwest monsoon. The southeast monsoon (April-October) is associated with easterlies from Australia that carry warm and dry air over the region. On the other hand, the northwest monsoon (wet season) is associated with westerlies from the Asian continent that carry warm and moist air to the region.

Generally, increasing anomaly of rainfall and SST in Indonesia 2010 is caused by La Nina Modoki phenomenon which is part of cooling at ENSO Modoki (Platonov et al., 2012). ENSO Modoki is a recurring pattern of used climate variability in the central equatorial Pacific that is characterized by anomalies in both seasurface temperature (referred to as El Niño and La Niña for warming and cooling periods, respectively) and sea level pressure (Southern Oscillation; Philander, 1990). In 2010, index value of El Nino Modoki Index (EMI) which is one of the characteristic of El Nino and La Nina Modoki phenomenon (Ashok et al., 2007), shown that negative value as the indicator of La Nina. According to IRI (2010), La Nina phenomenon began from June. Besides La Nina effect, SST local condition in Indonesia Sea also have important think in increasing of rainfall in Indonesia. Warm SSTs around the islands of the Indonesia lead to vast amounts of evaporation triggering surface heat flux, which drive the deep convective cell over the region (Qu et al., 2005). During cooler SST in center of Pacific (La Nina), SST condition in Indonesia Sea has warmer than normal condition. This condition caused the southeast monsoon and east-west zonal wind which are the source of convection in Indonesia run up. The SST warmer also increased evapotranspiration processes which are water vapor resource for beginning the rain.

Another explanation about the increase in precipitation during La Niña is also caused by anomalies in wind direction. During La Niña, the surface wind response to SST anomalies outside the equatorial Pacific is similar to those associated with El Niño with the sign reversed although the anomalous westerly winds over the far western Pacific are stronger and extend less to the east compared to the anomalous easterly winds during El Niño. Thus, SST anomalies outside the equatorial Pacific produce a negative feedback during both El Niño and La Niña and caused rainfall anomalies. In the equatorial region, the Sun transfers maximum energy to surface waters of the ocean. Under normal, non-El Niño/La Niña conditions, the trade winds blow toward the west across the surface of the tropical Pacific Ocean. These strong, constant winds push and drag the warm surface water westward, "piling" it up and holding it in the western Pacific Ocean basin. The sea-surface level is normally about one-half meter higher in Indonesia than it is in Peru (Water Encyclopedia, 2011).

The SST forcing depends on the mean SST. Thus, the atmospheric response to local SST forcing tends to be larger and faster in regions of high mean SST. The strong seasonality in the SST forcing may be reasonably explained by the seasonal movement of warm SST regions. The SST response to the atmosphere depends on the mean mixed-layer depth and surface heat flux variability ( $\mathrm{Wu}$ et al., 2008). The atmosphere and the ocean are intimately connected. Ocean temperatures influence rainfall patterns throughout the world, so when ocean temperatures change, rainfall patterns tend to change as well. Warm SST anomalies lead to enhanced evaporation and more rain, and cool SST anomalies lead to less evaporation and less rain. Further, they are consistent with the atmospheric circulation anomalies: more rain where there is anomalous surface convergence and updrafts, and less rain where there is anomalous surface divergence and downdrafts (Saji and Yamagata, 2003).

\section{Conclusion}

Remote sensing data could observe the location of rainfall and SST anomaly in Indonesia. The anomaly of higher rainfall and SST in Indonesia 2010 is caused by La Nina Modoki effect. La Nina Modoki in 2010 begin from June, meanwhile climate anomaly and increasing of rainfall and SST generally begin from April to October. Seasonally, rainfall anomaly in Indonesia region occurs during southeast monsoon. Although not happening over Indonesia and only in the southern part of Indonesia. While during the northwest monsoon occurs outside of Indonesian region, especially in southwest and northwest part.

Rainfall and SST anomaly phenomenons are high during dry season. Meanwhile during rainy season, that seen does not explain unclear, whereas when it currently El Nino Modoki events. Spatio-temporal shown the rainfall and SST anomaly in Indonesia is in dynamic condition. Based on spatial and temporal pattern that produce could be conclude that the rainfall and SST anomaly is begin in April, with located in southwest and center part of Indonesia. During August to October, ENSO effect begins to leave the western part of Indonesia and moving to the north and south part of Indonesia. ENSO influence of November-December begin to leave Indonesia and moving to the southwest part of Indonesia. Generally, the location and Spatial pattern of SST and rainfall in Indonesia is the same. These indicate the relationship between local SST and local convective activity is highly sensitive, also local SST anomaly could affect local rainfall anomaly.

\section{References}

Aldrian, E., Gates, L. D., \& Widodo, F. H. (2007). Seasonal variability of Indonesian rainfall in ECHAM4 simulations and in the reanalyses: The role of ENSO. Theoretical and Applied Climatology, 87(1-4), 41-59.

Aldrian, E., \& Djamil, Y. S. (2008). Spatio - temporal climatic change of rainfall in East Java Indonesia. International Journal of Climatology, 28(4), 435-448.

Ashok, K., Behera, S.K., Rao, S. A., Weng, H., \& Yamagata, T. (2007). El Niño Modoki and its possible teleconnection. Journal of Geophysical Research: Oceans, 112(C11), C11007, 1-27.

As-syakur, A. R. (2010). Pola Spasial Pengaruh Kejadian La Nina Terhadap Curah Hujan di Indonesia Tahun 1998/1999; Observasi Menggunakan Data TRMM Multisatellite Precipitation Analysis (TMPA) 3B43. In XVII Annual Scientific Meeting of Indonesian Society for Remote Sensing (ISRS), Bogor-Indonesia, 9 August 2010 (pp. 230-234). 
As-syakur, A. R., \& Prasetia, R. (2010). Pola Spasial Anomali Curah Hujan Selama Maret Sampai Juni 2010 di Indonesia; Komparasi Data TRMM Multisatellite Precipitation Analysis (TMPA) $3 B 43$ dengan Stasiun Pengamat Hujan. In the Proceedings of the Environmental Problems Research in Indonesia, Denpasar-Indonesia, 9 July 2010 (pp. 505-516).

As-syakur, A. R., Tanaka, T., Osawa, T., \& Mahendra, M. S. (2013). Indonesian rainfall variability observation using TRMM multi-satellite data. International journal of remote sensing, 34(21), 7723-7738.

As-syakur, A. R., Tanaka, T., Prasetia, R., Swardika, I. K., \& Kasa, I. W. (2011). Comparison of TRMM multisatellite precipitation analysis (TMPA) products and daily-monthly gauge data over Bali. International journal of remote sensing, 32(24), 8969-8982.

As-syakur, A. R., Adnyana, I. W. S., Mahendra, M. S., Arthana, I. W., Merit, I. N., Kasa, I. W., Ekayanti, N. W., Nuarsa, I. W., \& Sunarta, I. N. (2014). Observation of spatial patterns on the rainfall response to ENSO and IOD over Indonesia using TRMM Multisatellite Precipitation Analysis (TMPA). International Journal of Climatology, 34(15), 3825-3839.

Balino, B. M., Fasham, M. J., \& Bowles, M. C. (2001). Ocean biogeochemistry and global change: JGOFS research highlights 1988-2000. IGBP Science, 2, 1-32.

Bell, G. D., Halpert, M. S., Kousky, V. E., Gelman, M. E., Ropelewski, C. F., Douglas, A. V., \& Schnell, R. C. (1999). Climate assessment for 1998. Bulletin of the American Meteorological Society, 80(5), s1-s48.

Bell, G. D., Halpert, M. S., Schnell, R. C., Higgins, R. W., Lawrimore, J., Kousky, V. E., Tinker, R., Thiaw, W., Chelliah, M., \& Artusa, A. (2000). Climate assessment for 1999. Bulletin of the American Meteorological Society, 81(6), s1-s50.

Feidas, H. (2010). Validation of satellite rainfall products over Greece. Theoretical and Applied climatology, 99(1-2), 193216.

Feng, J., \& Li, J. (2011). Influence of El Niño Modoki on spring rainfall over south China. Journal of Geophysical Research: Atmospheres, 116(D13), D13102, 1-10.

Hamada, J. I., Yamanaka, M. D., Matsumoto, J., Fukao, S., Winarso, P. A., \& Sribimawati, T. (2002). Spatial and temporal variations of the rainy season over Indonesia and their link to ENSO. Journal of the Meteorological Society of Japan, 80(2), 285-310.

Hendon, H. H. (2003a). Indonesian rainfall variability: Impacts of ENSO and local air-sea interaction. Journal of Climate, 16(11), 1775-1790.

Hendon, H. H. (2003b). Impacts of air-sea coupling on variability of the Indonesian monsoon. In Meighen, P. J., Hollis, A. J. (eds.), Current issues in the parameterization of convection. Australia: Bureau of Meteorology Research Centre, pp. 109-112.

Huffman, G.J. (1997). Estimates of root-mean-square random error for finite samples of estimated precipitation. Journal of Applied Meteorology, 36(9), 1191-1201.

Huffman, G. J., Adler, R. F., Rudolf, B., Schneider, U., \& Keehn, P. R. (1995). Global precipitation estimates based on a technique for combining satellite-based estimates, rain gauge analysis, and NWP model precipitation information. Journal of Climate, 8(5), 1284-1295.

Huffman, G. J., Adler, R. F., Arkin, P., Chang, A., Ferraro, R., Gruber, A., Janowiak, J., McNab, A., Rudolf, B., \& Schneider, U. (1997). The global precipitation climatology project (GPCP) combined precipitation dataset. Bulletin of the American Meteorological Society, 78(1), 5-20.
Huffman, G. J., Adler, R. F., Bolvin, D. T., \& Nelkin, E. J. (2010). The TRMM multi-satellite precipitation analysis (TMPA). In: Gebremichael, M., Hossian, F. (Eds.), Satellite Rainfall Applications for Surface Hydrology. Netherlands: Springer, pp. 3-22.

International Research Institute. (2013). Technical ENSO update. (http://iri.columbia.edu/climate/ENSO/currentinfo/ archive/index.html) [cited 17 June 2010].

Islam, M. N., \& Uyeda, H. (2007). Use of TRMM in determining the climatic characteristics of rainfall over Bangladesh. Remote Sensing of Environment, 108(3), 264276.

Kummerow, C., Simpson, J., Thiele, O., Barnes, W., Chang, A. T. C., Stocker, E., Adler, R. F., Hou, A., Kakar, R., Wentz, F., Ashcroft, P., Kozu, T., Hong, Y., Okamoto, K., Iguchi, T., Kuroiwa, H., Im, E., Haddad, Z., Huffman, G., Ferrier, B., Olson, WS., Zipser, E., Smith, EA., Wilheit, TT., North, G., Krishnamurti, T \& Nakamura, K. (2000). The status of the Tropical Rainfall Measuring Mission (TRMM) after two years in orbit. Journal of Applied Meteorology, 39(12), 19651982.

Li, G., Ren, B., Yang, C., \& Zheng, J. (2010). Indices of El Niño and El Niño Modoki: An improved El Niño Modoki index. Advances in Atmospheric Sciences, 27, 1210-1220.

Luo, J. J., Zhang, R., Behera, S. K., Masumoto, Y., Jin, F. F., Lukas, R., \& Yamagata, T. (2010). Interaction between El Nino and extreme Indian ocean dipole. Journal of Climate, 23(3), 726-742.

NASA. (2009). About MODIS. (http://www.modis.gsfc.nasa. gov/about/March/2009).

NOAA. (2010). Climate Diagnostics Bulletin; June 2010. National Oceanic and Atmospheric Administration, National Weather Service, National Centers for Environmental Prediction (http://www.cpc.ncep.noaa.gov/products/CDB).

Petty, G. W. (1995). The status of satellite-based rainfall estimation over land. Remote Sensing of Environment, 51(1), 125-137.

Philander, S. G. (1990). El Niño, La Niña and the Southern Oscillation. San Diego-US: Academic Press.

Platonov, V., Semenov, E., \& Sokolikhina, E. (2012). Extreme La-Nina 2010/11 and the vigorous flood at the north-east of Australia. In EGU General Assembly Conference Abstracts (Vol. 14, pp. 313).

Qu, T., Du, Y., Strachan, J., Meyers, G., \& Slingo, J. (2005). Sea surface temperature and its variability in the Indonesian region. Oceanography, 18(4), 50-61.

Saji, N. H., \& Yamagata, T. (2003). Possible impacts of Indian Ocean dipole mode events on global climate. Climate Research, 25(2), 151-169.

Suryantoro, A., Halimurrahman, T. H., \& Iklim, B. P. (2008). Aplikasi Satelit Tropical Rainfall Measuring Mission (TRMM) Untuk Prediksi Curah Hujan Di Wilayah Indonesia. In Prosiding Workshop Nasional Aplikasi Sains Atmosfer dan Iklim, LAPAN, Bandung-Indonesia, 2008.

Takahashi, H., Su, H., Jiang, J. H., Luo, Z. J., Xie, S. P., \& Hafner, J. (2013). Tropical water vapor variations during the 2006-2007 and 2009-2010 El Niños: Satellite observation and GFDL AM2. 1 simulation. Journal of Geophysical Research: Atmospheres, 118(16), 8910-8920.

Tjasyono, H. K., Lubis, A., Juaeni, I., \& Harijono, W. B. (2010). Dampak Variasi Temperatur Samudera Pasifik dan Hindia Ekuatorial Terhadap Curah Hujan di Indonesia. Jurnal Sains Dirgantara, 5(2), 1-13.

Water Encyclopedia. (2011) El Niño and La Niña. (http://www.waterencyclopedia.com/ Da-En/El-Ni-o-and-LaNi-a.html) [cited 23 December 2014]. 
Wu, R., Kirtman, B. P., \& Pegion, K. (2008). Local rainfall-SST relationship on subseasonal time scales in satellite observations and CFS. Geophysical Research Letters, 35(22), L22706.

Xie, P., Chen, M., Yang, S., Yatagai, A., Hayasaka, T., Fukushima, Y., \& Liu, C. (2007). A gauge-based analysis of daily precipitation over East Asia. Journal of Hydrometeorology, 8(3), 607-626.

Xie, F., Li, J., Tian, W., Zhang, J., \& Shu, J. (2014). The impacts of two types of El Niño on global ozone variations in the last three decades. Advances in Atmospheric Sciences, 31(5), 1113-1126.

(C) 2015 by the authors; licensee Udayana University, Indonesia. This article is an open access article distributed under the terms and conditions of the Creative Commons Attribution license (http://creativecommons.org/licenses/by/3.0/). 